\title{
Factors influencing the stability of senior executives in corporate hospitals of I ndia
}

\author{
Ravi Babu Koppala ${ }^{1}$, Kavita Vurity ${ }^{2}$, Mathew P Sherry ${ }^{1}$ \\ 1. Department of Hospital Administration, Vydehi Institute of Medical Sciences and Research Centre, Karnataka, India. \\ 2. Research Scholar \& Zonal Head HR, Fortis Escorts Heart Institute, New Delhi, India.
}

Correspondence: Ravi Babu Koppala, Associate Professor. Address: Department of Hospital Administration, Vydehi Institute of Medical Sciences and Research Centre, Whitefield, Bangalore, Karnataka (Pin: 560066), India. E-mail: piler2000@yahoo.com

Received: November 28, 2013

Accepted: January 5, 2014

Online Published: January 11, 2014

DOI : $10.5430 /$ jha.v3n3p61

URL: http://dx.doi.org/10.5430/jha.v3n3p61

\section{Abstract}

Objective: To assess the factors (both job motivating and de-motivating) influencing the stability of senior executives in corporate hospitals and to find out the correlates of those job motivating and de-motivating factors.

Methods: A cross sectional design was adopted for this study in which 14 factors were chosen to assess the level of job satisfaction using a five point Likert scale questionnaire. Seventy six senior executives with at least minimum 10 years of work experience from various corporate hospitals of India were interviewed using a non probability convenience sampling technique.

Results: Majority (more than 75\%) of the senior executives were satisfied with their job. Age, sex and work experience could not significantly affect the job satisfaction except for the stability of the job and salary and other added benefits.

Conclusion: The current study makes an important contribution to the literature in finding the determinants of job satisfaction among senior executives built upon evidence from the findings.

\section{Key words}

Job satisfaction, Hospital, Senior executive

\section{Introduction}

Job Satisfaction is one of the most widely explored subjects in the area of Organizational Behavior and Human Resource Management. Satisfied employees are more productive and committed to their jobs, whereas dissatisfied ones experience absenteeism, grievances and turnover ${ }^{[1]}$. There are five job dimensions that represent the most important characteristics of a job about which people have affective responses. These are: the work itself, Pay, Promotion opportunities, Supervision and Coworkers ${ }^{[2]}$. Job satisfaction has been defined as a general attitude towards one's job. According to Robins (1997) ${ }^{[3]}$, it is the difference between the amounts of rewards employees receive and the amount they believe they should receive. While investigating satisfaction level on the job, Herzberg (1952) ${ }^{[4]}$ has identified motivation factors (intrinsic factors) and hygiene factors (working conditions, salary, job security, company policy, supervisors and interpersonal relations). He concluded that motivating factors (e.g., achievement, recognition, advancement, responsibility, growth and work itself) lead to satisfaction on the job and factors like company policy and administration, supervision, and relationship with 
supervisor, peers and subordinates, work conditions, salary, personal life, status, and security may lead to job dissatisfaction. It has been also observed that all the motivating factors are intrinsic factors and are within the periphery of the job, while all the hygiene factors are extrinsic and are outside the periphery of the job.

Job satisfaction is an essential element for the maintenance of the workforce numbers of any organization. Unsatisfied workers report a higher intent to leave which leads to high turnover rates and have detrimental effect on the individual, like burnout (a syndrome where the worker experiences emotional exhaustion, depersonalization, and a reduced sense of personal accomplishment ${ }^{[5,6]}$. Although turnover also provides the organization with new ideas and is a normal process, it does not need to be unnecessary and excessive ${ }^{[7]}$. So, understanding job satisfaction is not only desirable but also a critical aspect of life for both individuals and organizations.

The growth of managed care has major financial implications for health care delivery. One of the major implications is the quality of care which is directly affected by the quality of work of hospital administrators and the level of satisfaction they see in their jobs. Organizational growth and development primarily depends on the efficiency of management. Executives lead organization towards the success in order to materialize the goal of the company. When they are satisfied with their jobs they will be motivated and more efficient towards their responsibilities. As such, job satisfaction of senior executives plays an important role for the betterment of the organization.

With this background this study was planned with the following objectives.

\section{Objectives}

To assess the factors (both job motivating and de-motivating) influencing the stability of senior executives in corporate hospitals and to find out the correlates of those job motivating and de-motivating factors.

\section{Methods}

\subsection{Period of study}

This study was conducted for a period of eight months. Initial two weeks were utilized for extensive literature search and designing and finalization of interview schedule. Next seven months were utilized for data collection, data entry and quality check. Data analysis and write up were done in last two weeks.

\subsection{Study design}

A hospital based cross sectional study design was adopted for this study.

\subsection{Sampling methodology}

A hypothesis had been formulated to check the factors (both job motivating and de-motivating) influencing the stability of senior executives in corporate hospitals. It is an analytical type of research where data has been collected from various level of senior executives like CEO, COO, Medical Directors, Executive director, VP Operations and medical services, Chief administrator, Senior manager operations, Director operations, Hospital administrator, GM operations, Head operations, Zonal head operations, Senior administrator, Head administration, Facility director, Joint director medical services, Managing director, Medical superintendent, Senior manager, etc. At the time of study, those senior executives were representing various corporate hospitals spread across whole India (Andhra Pradesh, Karnataka, Kerala, West Bengal, Delhi, Chhattisgarh, Maharashtra, Uttar Pradesh, Tamilnadu and Haryana).

A sample of 76 senior executives working in corporate hospitals preferably with minimum 10 years of work experience and at least five years experience in corporate hospital has been drawn using a non probability convenience sampling 
technique. Those senior executives were contacted personally and data was collected using a tool after explaining them the purpose of the study. A sample size of 76 was targeted due to limited resources, such as limited amount of time, and budget constraints.

Fourteen variables were included to assess the factors (10 job-motivating and 4 job-demotivating) influencing their stability in corporate hospitals. A five point Likert type scale has been used in the questionnaire, where the scale rates 5 for strongly agree (SA), 4 for agree (A), 3 for neither agree nor disagree (NAD), 2 for disagree (D) and 1 for strongly disagree (SD).

The study conformed to the ethical principles of informed consent, confidentiality of information and autonomy. Study participants were explained that they were free to withdraw at any point of time of the interview. Privacy and confidentiality during the data collection process was maintained to the extent possible.

\subsection{Analysis of data}

Data thus generated was analyzed using Microsoft excel 2007 and SPSS v.20 software. Job Satisfaction Index (JSI) ${ }^{\text {[9] }}$ was calculated by appropriate calculations. Since the data is primarily categorical in nature (5-point Likert scale), nonparametric (Mann-Whitney U and Kruskal Wallis with post hoc analysis of Dunn) tests were adopted to test the hypotheses.

\section{Results}

A total 76 respondents could be successfully interviewed during the study period (see Table 1). Mean age of the respondentswas $47.18+19.71$ years which ranged from 29 years to 68 years. Majority $(86.8 \%)$ of the respondents were male. Nearly half $(51.3 \%)$ of the interviewed senior executives were belonging to MBBS stream. As far as the work experience is concerned, it ranged from 10 years to 42 years with a mean of $19.71+9.34$ years.

Table 1. Profile of respondents

\begin{tabular}{lll}
\hline Variables & N & Percentage \\
\hline Age groups (Years) & 22 & 28.9 \\
$<40$ & 26 & 34.2 \\
$40-49$ & 28 & 36.8 \\
$\geq 50$ & & 86.8 \\
Sex & 66 & 13.2 \\
Male & 10 & \\
Female & & 51.3 \\
Qualification & 39 & 48.7 \\
MBBS graduate and above & 37 & \\
Other than MBBS graduates & & 44.7 \\
Work Experience (Years) & 34 & 22.4 \\
$<15$ & 17 & 32.9 \\
$15-24$ & 25 & 100.0 \\
$\geq 25$ & 76 & \\
\hline Total & & \\
\hline
\end{tabular}

Table 2 shows the descriptive statistics in terms of median, mode, range and Inter Quartile Range of scores of the factors (both job motivating and de-motivating) influencing the stability of senior executives in corporate hospitals which were assessed in the study. Studied job motivating factors include expectations of owners or management from them, regular appreciation and support by higher authority, subordinate staff/people's respect and appreciation for their work, stable job 
and income, love for the work, conducive working environment in hospital, sense of achievement and recognition, competency for the work, brand value of the hospital and various other perquisite. While studied de-motivating factors include lack of facilities in the hospital, undue work pressure, family or personal hindrance factors and various better opportunities outside the hospital.

Table 2. Descriptive statistics for the factors (both job motivating and de-motivating) used in the study

\begin{tabular}{lllllll}
\hline S. No. & Factors & N & Median & Mode & Range & IQR $^{*}$ \\
\hline 1 & Expectations of Owners or Management & 76 & 4 & 4 & 4 & 1 \\
2 & Appreciation and support by Higher authority & 76 & 5 & 5 & 2 & 1 \\
3 & Subordinate staff/People's respect/appreciation for my work & 76 & 5 & 5 & 3 & 1 \\
4 & Stable job and income & 74 & 5 & 5 & 3 & 1 \\
5 & Love for the work & 76 & 5 & 5 & 3 & 0 \\
6 & Conducive working environment & 76 & 5 & 5 & 2 & 1 \\
7 & Career path/Sense of achievement and recognition & 76 & 5 & 5 & 2 & 1 \\
8 & Competencies & 76 & 5 & 5 & 4 & 1 \\
9 & Brand value & 76 & 4 & 5 & 4 & 3 \\
10 & Perquisite & 76 & 4 & 5 & 3 \\
11 & Lack of facilities & 75 & 2 & 1 & 4 \\
12 & Work Pressure & 75 & 3 & 3 & 4 & 3 \\
13 & Family or Personal factors & 75 & 3 & 2 & 4 \\
14 & Better Outside Opportunities & 75 & 3 & 1 & 4 \\
\hline
\end{tabular}

"IQR - Inter Quartile Range

\section{J ob satisfaction index for the senior executives of hospitals}

There is a five-point scale in the questionnaire based on which the employee responses range from 5 for strongly agree (SA), 4 for agree (A), 3 for neither agree nor disagree (NAD), 2 for disagree (D) to 1 for strongly disagree (SD).

The total number of questions with answers against each response is calculated $(5,4,3,2,1)$.

The Total Score Received $=($ total number of responses of $5 * 5)+($ total number of responses of $4 * 4)+($ total number of responses of $3 * 3)+($ total number of responses of $2 * 2)+($ total number of responses of $1 * 1)$.

Maximum Total Score is calculated 10 (number of job motivating questions) $* 5$ (maximum response) $* 76$ (number of respondents).

This gives the Index which is the (Total Score Received/Maximum Total Score) * 100 .

Thus JSI $=($ Total Score Received/Maximum Total Score $) * 100=(3369 / 3800) * 100=88.66$.

The Job Satisfaction Index of the employees at study hospital is in a scale of 100 is 88.66 .

Majority (more than 78\%) of the senior executives were satisfied with expectations of owners or management, appreciation and support by higher authority, subordinate staff/people's respect and appreciation for their work, stability of job and income, their love for the work, conducive working environment of hospital, career path opportunities/sense of achievement and recognition, competencies for the work and brand value of the hospital. Other added benefits for the employees in the hospital were job motivating factors for $71 \%$ of the senior executives. As far as the job de motivating factors are concerned, $32.9 \%$ senior executives claimed better opportunities outside the hospital. Family or personal 
problems were de motivating $36.8 \%$ senior executives. Heavy work load was a hindrance factor for nearly $29 \%$ respondents. As much as $27.6 \%$ senior executives claimed lack of proper facilities in hospital as their job de-motivating factor (see the Figure).

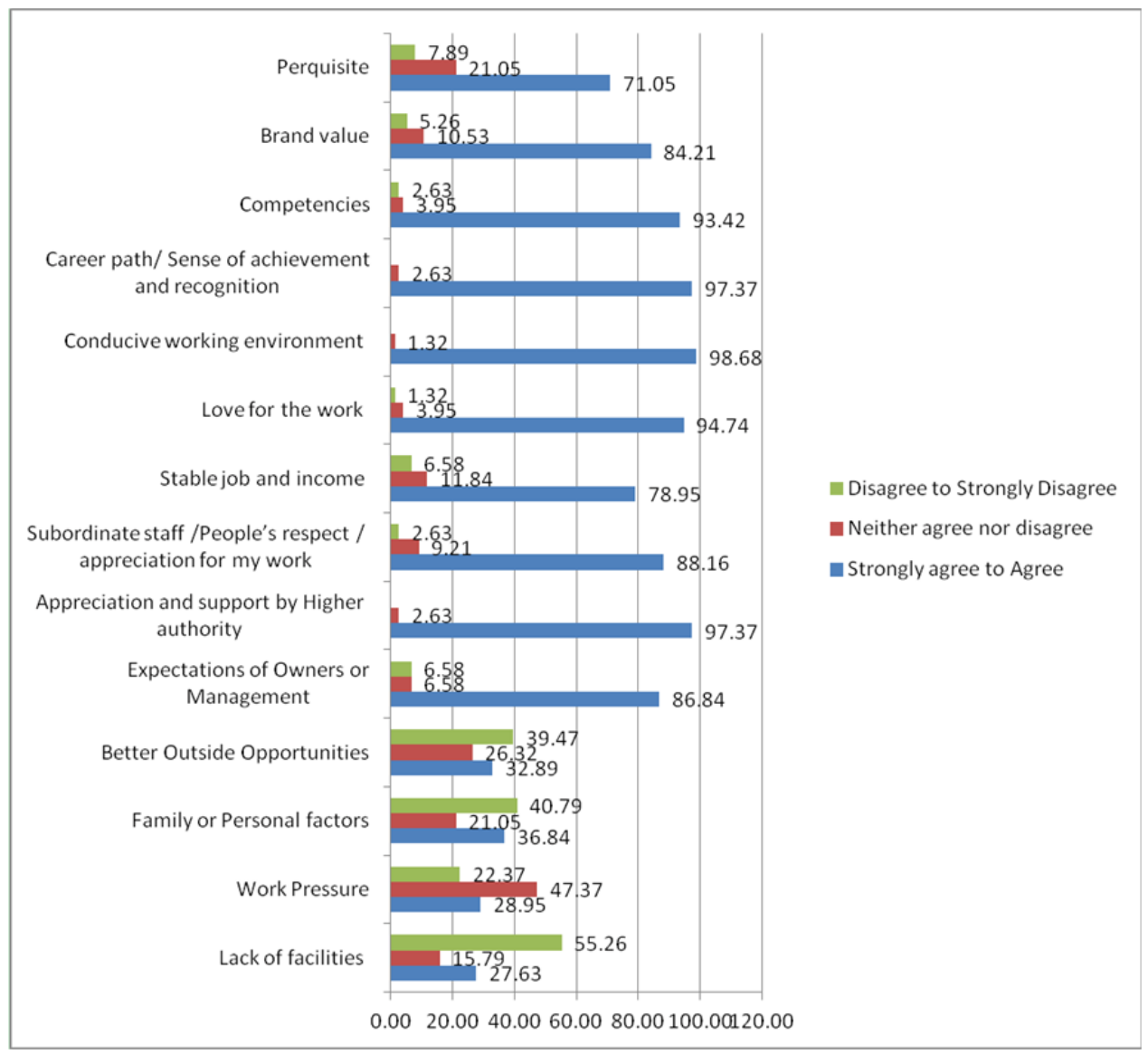

Figure. Status of job motivating and de-motivating factors

Table 3. Factors affecting job stability vis-a-vis gender of the senior executives

\begin{tabular}{|c|c|c|c|c|c|}
\hline \multirow{2}{*}{ S. No. } & \multirow{2}{*}{ Factors } & \multicolumn{2}{|c|}{ Mean Rank } & \multirow{2}{*}{$\begin{array}{l}\text { Mann- } \\
\text { Whitney U }\end{array}$} & \multirow{2}{*}{$p$ value } \\
\hline & & Male & Female & & \\
\hline 1 & Expectations of Owners or Management & 38.33 & 39.65 & 318.5 & .846 \\
\hline 2 & Appreciation and support by Higher authority & 36.98 & 48.5 & 230 & .045 \\
\hline 3 & Subordinate staff/People's respect/appreciation for my work & 37.37 & 45.95 & 255.5 & .201 \\
\hline 4 & Stable job and income & 35.7 & 49 & 205 & .046 \\
\hline 5 & Love for the work & 37.89 & 42.5 & 290 & .248 \\
\hline 6 & Conducive working environment & 37.52 & 45 & 265 & .234 \\
\hline 7 & Career path/Sense of achievement and recognition & 37.39 & 45.8 & 257 & .155 \\
\hline 8 & Competencies & 37.38 & 45.9 & 256 & .184 \\
\hline 9 & Brand value & 37.06 & 48 & 235 & .113 \\
\hline 10 & Perquisite & 36.14 & 54.1 & 174 & .011 \\
\hline 11 & Lack of facilities & 39.53 & 28.05 & 225.5 & .109 \\
\hline 12 & Work Pressure & 38.12 & 37.2 & 317 & .894 \\
\hline 13 & Family or Personal factors & 38.05 & 37.65 & 321.5 & .955 \\
\hline 14 & Better Outside Opportunities & 36.67 & 46.65 & 238.5 & .166 \\
\hline
\end{tabular}

Published by Sciedu Press 
Table 3 shows that the female senior executives were found more satisfied with their job compared to male senior executives, but this relation was not statistically significant. In comparison to male senior executives, female senior executives were found to have significantly $(p<.05)$ higher rank in terms of the stability of the job, stability of salary and with the other added benefits viz. accommodation, food, and incentives which they were getting in the hospital.

Table 4. Factors affecting job stability vis-a-vis age of the senior executives

\begin{tabular}{|c|c|c|c|c|c|c|}
\hline \multirow{2}{*}{ S. No. } & \multirow{2}{*}{ Factors } & \multicolumn{3}{|c|}{ Mean Rank (age in years) } & \multirow{2}{*}{$\begin{array}{l}\text { Kruskal } \\
\text { Wallis Test }\end{array}$} & \multirow{2}{*}{$p$ value } \\
\hline & & $<40$ & $40-49$ & $\geq \mathbf{5 0}$ & & \\
\hline 1 & Expectations of Owners or Management & 37.23 & 38.21 & 39.77 & 0.204 & .903 \\
\hline 2 & Appreciation and support by Higher authority & 40.09 & 34.92 & 40.57 & 1.777 & .411 \\
\hline 3 & $\begin{array}{l}\text { Subordinate staff/People's respect/appreciation for } \\
\text { my work }\end{array}$ & 40.61 & 34.12 & 40.91 & 1.945 & .378 \\
\hline 4 & Stable job and income & 40.36 & 29.28 & 42.78 & 6.839 & .033 \\
\hline 5 & Love for the work & 39.23 & 36.48 & 39.8 & 1.195 & .55 \\
\hline 6 & Conducive working environment & 39.93 & 38.08 & 37.77 & 0.189 & .91 \\
\hline 7 & Career path/ Sense of achievement and recognition & 41.09 & 34.42 & 40.25 & 2.19 & .335 \\
\hline 8 & Competencies & 39.48 & 36.23 & 39.84 & 0.575 & .75 \\
\hline 9 & Brand value & 40.32 & 35.73 & 39.64 & 0.747 & .688 \\
\hline 10 & Perquisite & 38.68 & 32.65 & 43.79 & 3.82 & .148 \\
\hline 11 & Lack of facilities & 35.84 & 37.16 & 40.45 & 0.647 & .724 \\
\hline 12 & Work Pressure & 34.95 & 36.86 & 41.41 & 1.359 & .507 \\
\hline 13 & Family or Personal factors & 34.45 & 42.02 & 37.2 & 1.573 & .455 \\
\hline 14 & Better Outside Opportunities & 39.05 & 38.94 & 36.34 & 0.274 & .872 \\
\hline
\end{tabular}

Table 5. Factors affecting job stability vis-a-vis work experience of the senior executives

\begin{tabular}{|c|c|c|c|c|c|c|}
\hline \multirow{2}{*}{ S. No. } & \multirow{2}{*}{ Factors } & \multicolumn{3}{|c|}{ Mean Rank (Work experience in years) } & \multirow{2}{*}{$\begin{array}{l}\text { Kruskal } \\
\text { Wallis Test }\end{array}$} & \multirow{2}{*}{$p$ value } \\
\hline & & $<15$ & 15-24 & $\geq 25$ & & \\
\hline 1 & Expectations of Owners or Management & 34.76 & 42.12 & 41.12 & 2.141 & .343 \\
\hline 2 & Appreciation and support by Higher authority & 37.62 & 36.44 & 41.1 & 0.935 & .627 \\
\hline 3 & $\begin{array}{l}\text { Subordinate staff/People's respect/appreciation } \\
\text { for my work }\end{array}$ & 37.68 & 34.35 & 42.44 & 1.798 & .407 \\
\hline 4 & Stable job and income & 31.24 & 39.56 & 45 & 7.181 & .028 \\
\hline 5 & Love for the work & 35.78 & 40.18 & 41.06 & 3.35 & .187 \\
\hline 6 & Conducive working environment & 34.44 & 45.88 & 39 & 4.352 & .113 \\
\hline 7 & Career path/Sense of achievement and recognition & 36.12 & 37.97 & 42.1 & 1.717 & .424 \\
\hline 8 & Competencies & 33.51 & 44.65 & 41.1 & 4.64 & .098 \\
\hline 9 & Brand value & 35.84 & 41.88 & 39.82 & 1.158 & .56 \\
\hline 10 & Perquisite & 34.15 & 36.62 & 45.7 & 4.571 & .102 \\
\hline 11 & Lack of facilities & 38.89 & 34.94 & 38.9 & 0.462 & .794 \\
\hline 12 & Work Pressure & 37.62 & 37.44 & 38.88 & 0.071 & .965 \\
\hline 13 & Family or Personal factors & 40.61 & 37.41 & 34.96 & 1.038 & .595 \\
\hline 14 & Better Outside Opportunities & 40.58 & 37.18 & 35.16 & 0.96 & 619 \\
\hline
\end{tabular}

Table 4 and Table 5 show that age and work experience in terms of time (years) could not have significant influence on job motivation and de-motivation of senior executives in the corporate hospitals except for the stability of the job and salary. By doing further post hoc analysis it was found that sense of job security was significantly (0.008) high in senior executives who had more than 25 years of work experience in comparison to those who had less than 15 years of work 
experience. Further post hoc analysis for age showed that sense of job security was significantly (0.013) higher in senior executives who belonged to more than 50 years of age group in comparison to those who belonged to 40 years to 49 years of age group.

Table 6. Factors affecting job stability vis-a-vis qualification of the senior executives

\begin{tabular}{|c|c|c|c|c|c|}
\hline \multirow{2}{*}{ S. No. } & \multirow{2}{*}{ Factors } & \multicolumn{2}{|c|}{ Mean Rank (qualification) } & \multirow{2}{*}{$\begin{array}{c}\text { Mann- } \\
\text { Whitney U }\end{array}$} & \multirow{2}{*}{$p$ value } \\
\hline & & MBBS & Other than MBBS & & \\
\hline 1 & Expectations of Owners or Management & 39.14 & 37.82 & 696.5 & .776 \\
\hline 2 & Appreciation and support by Higher authority & 37.81 & 39.23 & 694.5 & .714 \\
\hline 3 & Subordinate staff/People's respect/appreciation for my work & 36.59 & 40.51 & 647 & .387 \\
\hline 4 & Stable job and income & 30.73 & 44.27 & 434 & .003 \\
\hline 5 & Love for the work & 37.56 & 39.49 & 685 & .476 \\
\hline 6 & Conducive working environment & 40 & 36.92 & 663 & .469 \\
\hline 7 & Career path/Sense of achievement and recognition & 36.22 & 40.91 & 632.5 & .241 \\
\hline 8 & Competencies & 35.1 & 42.08 & 589 & .108 \\
\hline 9 & Brand value & 31.37 & 46.01 & 443.5 & .002 \\
\hline 10 & Perquisite & 28.88 & 48.64 & 346.5 & .001 \\
\hline 11 & Lack of facilities & 41.05 & 34.86 & 587 & .204 \\
\hline 12 & Work Pressure & 37.64 & 38.36 & 689.5 & .878 \\
\hline 13 & Family or Personal factors & 37.17 & 38.85 & 671.5 & .73 \\
\hline 14 & Better Outside Opportunities & 35.86 & 40.2 & 621.5 & .375 \\
\hline
\end{tabular}

Table 6 shows the effect of qualification of senior executives on the stability of their job in corporate hospitals. In comparison to senior executives who were belonging to MBBS stream, senior executives who were belonging to other than MBBS stream were found to have significantly $(p<.05)$ higher rank of satisfaction in terms of the stability of the job, stability of salary, brand value of the hospital and with the other added benefits from the hospital.

\section{Discussion}

Job satisfaction and occupational success are major factors in personal satisfaction, self-respect, self-esteem, and self-development. To the worker, job satisfaction brings a pleasurable emotional state that can often leads to a positive work attitude. A satisfied worker is more likely to be creative, flexible, innovative, and loyal and will tend to add more value to an organization. In the present study it was found that variety of factors acts as the job motivating and de-motivating factors for senior executives in corporate hospitals. Those factors affect their dedication regarding professional behaviour and can turn them to find out some alternate ways of job satisfaction. A descriptive, co-relational and cross-sectional study conducted by Mosadeghrad Ali Mohammad et al. (2008) ${ }^{[8]}$ indicated that employees' job satisfaction and organizational commitment were closely inter-related and correlated with turnover intention. Morrison, et al. (2007) ${ }^{[9]}$ outlined several ways in which the lack of engagement and high turnover rates impact health care organizations. Some of these factors include turnover costs, which according to Waldman \& Kelly (2004) ${ }^{[10]}$ range between $3.4 \%$ and $5.8 \%$ of their operating budget. However, present study is deficient in exploring those factors.

In the present study The Job Satisfaction Index of the employees at study hospital is in a scale of 100 is 88.66 which is higher than the Job Satisfaction Index calculated for employees in a tertiary care hospital in a study conducted by Yafe SA $(2011)^{[11]}$. Mosadeghrad A M and Ferdosi M (2013) ${ }^{[12]}$ had also shown higher job satisfaction among employees who were at higher occupational positions.

Expectations of Owners or Management, appreciation and support by higher authority, subordinate staff/people's respect and appreciation for the work and career path or sense of achievement and recognition were main factors found 
responsible for higher level of job satisfaction and retention in the hospital for senior executives. Knoop R (1994) ${ }^{[13]}$ and Troyer L et al. (1997) ${ }^{[14]}$ showed that the top managers and leaders of structural units at the hospital form a distinct group. The job satisfaction of those working in leading positions is influenced by the availability of opportunities for professional development. By virtue of their positions of authority, senior executives are most motivated by possibilities for growth and the achievement of objectives. Studies conducted by Ali-Mohammed (2004) ${ }^{[15]}$ and De Stefano et al. (2005) ${ }^{[16]}$ also showed in their studies that the opportunity to develop was a significant predictor of job satisfaction among study participants, means greater the chances for development within the organization, the greater the likelihood of a higher level of job satisfaction. Mosadeghrad A M and Ferdosi M (2013) ${ }^{[12]}$ had also shown lack of respect and recognition as reasons for employees' dissatisfaction.

Non conducive working environment points-out the organizational culture. In the present study, it was found that conducive-working environment, stable job and income and love for the work were the job motivating factors. This is contrary to the findings of the study conducted by Marina Kaarna (2006) ${ }^{[17]}$, which showed that collegial relationships and recognition have little significant impact on job satisfaction. Findings of the present study are supported by Finnish studies ${ }^{[18]}$ and Buciuniene et al. (2003) ${ }^{[19]}$ which had confirmed the importance of collegiality and supportive supervisory relationships in job satisfaction. Piko et al. (2006) ${ }^{[20]}$ also suggested that there is a strong association between job satisfaction and organizational factors.

The extent to which employees experience psychological or personal job satisfaction within the job content environment determines the quality and quantity of their outputs ${ }^{[21]}$. A study by Jain et al. (2009) ${ }^{[22]}$ also evaluated the level of job satisfaction in relation to different work and environmental factors. Lack of facilities, work pressure/work load, family or personal factors and better opportunities outside the hospital were major studied job de-motivating factors for senior executives. These findings are supported by the survey conducted by Buciuniene et al. (2003) ${ }^{[19]}$ which showed that compensation, social status and workload caused the highest level of dissatisfaction among employees. Nassab's (2008) ${ }^{[23]}$ and De Stefano et al. (2005) ${ }^{[16]}$ also showed that work and time pressure was strongly and positively associated with job dissatisfaction. Reduction in working hours may increase job satisfaction; however shift work may imply working unsociable hours and negatively impact on job satisfaction.

In the present study it was found that age, sex and duration of work experience could not significantly affect the job satisfaction except for the stability of the job and salary and other added benefits. A study by Bodur (2001) ${ }^{[24]}$, which also did not find any correlation between job satisfaction and demographic characteristics, supports the findings of the present study. But these findings are contrary to findings of Al-Eisa Ibrahim S et al. (2005) ${ }^{[25]}$ and Gigantesco et al. (2003) ${ }^{[26]}$, which proved that significantly the higher the age the higher the job satisfaction. Shah, M.A et al. $(2001)^{[27]}$ showed that employees with longer experience were more satisfied with their jobs than those with short experience.

In the present study in comparison to senior executives who were belonging to MBBS stream, senior executives who were belonging to other than MBBS stream were found to have significantly higher rank of job satisfaction in terms of the stability of the job, stability of salary, brand value of the hospital and with the other added benefits from the hospital. In a study conducted by Shah et al. (2001) ${ }^{[27]}$ on correlates of job satisfaction, revealed a significant relationship between educational level and job satisfaction and respondents with a diploma reported the highest level of job satisfaction.

\section{Conclusion}

There are many factors that contribute to satisfaction as well as dissatisfaction in the work place. According to the study conducted, senior executives in those corporate hospitals seemed to be quite satisfied with their jobs and no association was found between socio-demographic characteristics and job satisfaction. However, there is a need to incorporate a coordinated approach, involving partnership with a range of stakeholders by enhancing the job motivating factors and 
reducing the job de-motivating factors among senior executives of corporate hospitals. Thus, the current study makes an important contribution to the literature in finding the determinants of job satisfaction among senior executives built upon evidence from the findings. Besides that there is a scope and need to explore those factors with some comparative multi centric studies with senior executives of Govt. and other private hospitals.

\section{Limitations of the study}

Due to constraints of resources, the study is limited to small sample size i.e. only 76 senior executives.

The data was obtained through questionnaire (5-point Likert scale) which has its own limitations.

\section{Acknowledgement}

This work would not have been possible without the support of my professional colleagues working in different positions in different corporate hospitals.

\section{Ethical clearance}

The study was conformed to the ethical guidelines of the Vydehi Institute of Medical Sciences and Research Centre, Bangalore, Ethical Review Board. It had been reviewed and granted approval by the Board.

\section{Conflict of interests}

The authors declare that they have no conflict of interests.

\section{References}

[1] Smith D. Increasing Employee Productivity, Job Satisfaction, and Organizational Commitment. Hosp Health Serv Adm. 1996; 41: 160-174. Available from: http://www.ncbi.nlm.nih.gov/pubmed/10157961

[2] Smith PC, Kendall LM, Hulin CL. The measure of satisfaction in work and retirement, Rand McNally, Chicago. 1969. Available from: http://books.google.co.in/books/about/The_measurement_of_satisfaction_in_work.html?id=UcZEAAAAIAAJ

[3] Robins Stephen P. Organizational Behavior: Concepts, Controversies, Applications. 8th Ed. ISBN-10: 0138574596 | ISBN-13: 9780138574598. 1997. Available from: http://www.ebay.com/ctg/Organizational-Behavior-Concepts-Controversies-Applications-Vol-2-Stephen-P-Robbins-1997-CD-R OM-/56060

[4] Herzberg, F., Mausner, B., Synderman, B. The Motivation to Work, John Willy \& Sons 1959, New York. 157 p. 1952. Available from: http://www.garfield.library.upenn.edu/classics1984/A1984SP02300001.pdf

[5] Mrayyan MT. Nurse job satisfaction and retention: comparing public to private hospitals in Jordan. J of Nursing Management. 2005; 13(1): 40-50. Available from: http://www.ncbi.nlm.nih.gov/pubmed/15613093. PMid: 15613093. http://dx.doi.org/10.1111/j.1365-2834.2004.00453.x

[6] E. G. Lambert, N. L. Hogan, I. Altheimer. An exploratory examination of the consequence of burnout in terms of life satisfaction, turnover intent, and absenteeism among private correctional Staff. The Prison Journal. 2010; 90(1): 94-114. Available from: http://tpj.sagepub.com/content/90/1/94.short. http://dx.doi.org/10.1177/0032885509357586

[7] Marquis BL, Huston JC. 2003 Leadership roles and management functions in nursing theory \& application.4th ed. Philadelphia: JB Lippincott. Available from:

http://books.google.co.in/books/about/Leadership_Roles_and_Management_Function.html?id=38mzZLwcOe0C

[8] Mosadeghrad AM, Ferlie E, Rosenberg D. A study of the relationship between job satisfaction, organizational commitment and turnover intention among hospital employees' Health Services Management Research. 2008 Nov; 21(4): 211-27. Available from: http://www.ncbi.nlm.nih.gov/pubmed/18957399. http://dx.doi.org/10.1258/hsmr.2007.007015

[9] Morrison, Eileen E., Burke, III, George C., Greene, Lloyd. Meaning in Motivation: Does your organization need an inner life? Journal of Health \& Human Services Administration. 2007; 30(1): 98-115. PMid: 17557698.

[10] Waldman, J. D., Kelly, F., Arora, S., Smith H. L. The shocking cost of turnover in health care, Health Care Management Review. 2004; 29(1): 2-7. http://dx.doi.org/10.1097/00004010-200401000-00002 
[11] YAFE S A, Assessing job satisfaction level of employees in a tertiary care hospital -a tool for talent retention. International Journal of Multidisciplinary Research. 2011; 1(8): 494-507. ISSN 2231 5780. Available from: http://www.zenithresearch.org.in/images/.../40_VOL\%201_ISSUE8_ZEN.pdf

[12] Mosadeghrad A M, Ferdosi M. Leadership, Job Satisfaction and Organizational Commitment in Healthcare Sector: Proposing and Testing a Model. Mater Sociomed. 2013; 25(2): 121-26. http://dx.doi.org/10.5455/msm.2013.25.121-126

[13] Knoop R. Work, values and job satisfaction. J Psychol. 1994; 128: 683-690. http://dx.doi.org/10.1080/00223980.1994.9921297

[14] Troyer L. Younts WC. Whose expectations matter? The relative power of first and second order expectations in determining social influence. Am J Sociol. 1997; 103: 692-732. http://dx.doi.org/10.1086/231253

[15] Ali-Mohammed, M.R. Factors affecting employees' job satisfaction in public hospitals: Implications for recruitment and retention, Journal of General Management. 2004; 34(4): 51-66.

[16] DeStefano, T.J., Clark, H., Gavin, M., Potter, T. The relationship between work environment factors and job satisfaction among rural behavioral health professionals, Rural Mental Health. 2005; 30: 18-24. Available from: http://www.marshall.edu/jrcp/destefano.pdf

[17] Marina Kaarna. 2006. The importance of job satisfaction in hospital quality process, ISSN 1104-5701, ISBN 978-91-85721-04-7. http://www.nhv.se/upload/dokument/forskning/Publikationer/MPH/2007/MPH2007-4_Marina_Kaarna.pdf

[18] Kinnunen U, Mauno S, Nätti J, Happonen M. Organizational antecedents and outcomes of job insecurity: a longitudinal study in three organizations in Finland. J Organ Behav. 2000; 21: 443-459. http://dx.doi.org/10.1002/(SICI)1099-1379(200006)21:4<443::AID-JOB24>3.0.CO;2-N

[19] Buciuniene, I., Blazeviciene, A., Bliudziute, E. Health care reform and job satisfaction of primary health care physicians in Lithuania, BMC Family Practice. 2003; 6: 6-10. Available from: http://www.ncbi.nlm.nih.gov/pmc/articles/PMC555592/

[20] Piko, B.F. Burnout, role conflict, job satisfaction and psychosocial health among Hungarian health care staff: A questionnaire survey, International Journal of Nursing Studies. 2006; 43: 311-318. PMid: 15964005. http://dx.doi.org/10.1016/j.ijnurstu.2005.05.003

[21] Nel, P.S., Van Dyk, P.S., Haasbroek, G.D., Schultz, H.B., Sono, T.J., Werner, A. Human Resources Management. Sixth Edition. Cape Town: Oxford. 2004.

[22] Jain, M., Mathur, S., Joshi, S., Goklani, P., Kothari, B., Prabu, D., et al. Job satisfaction assessment among dentists and dental auxiliaries in India, Journal of Dental Science. 2009; 7: 2.

[23] Nassab, R. Factors influencing job satisfaction amongst plastic surgical trainees: experience from a regional unit in the United Kingdom, European Journal of Plastic Surgery. 2008; 31: 55-58. http://dx.doi.org/10.1007/s00238-008-0240-4

[24] Bodur, S. Job satisfaction of healthcare staff employed at health centers in Turkey, Occupational Medicine Journal. 2002; 52(6): 353-355.

[25] Al-Eisa Ibrahim S, Manal S Al-Mutar, Huda K Al-Abduljalil. Job Satisfaction of Primary Health Care Physicians at Capital Health Region, Kuwait' Middle east journal of family. 2005; 3(3). Available from: http://www.mejfm.com/journal/July05/Job-Satisfaction.htm

[26] Gigantesco, A., Picardi, A., Chiaia, E., Balbi, A. Morosini, P. Job satisfaction among mental health professionals in Rome, Italy. Community Mental Health Journal. 2003; 39: 349-355. PMid: 12908648. http://dx.doi.org/10.1023/A:1024076209376

[27] Shah, M.A., Al-Enezi, N., Chowdhury, R.I. Shah, N.M. Correlates of job satisfaction among health care professionals in Kuwait. Medical Principles and Practice. 2001; 10: 156-162. http://dx.doi.org/10.1159/000050361 